\title{
Androgen ablation results in differential regulation of transforming growth factor- $\beta$ isoforms in rat male accessory sex organs and epididymis
}

\section{K V Desai and P Kondaiah}

\author{
Department of Molecular Reproduction, Development and Genetics, Indian Institute of Science, \\ Bangalore-560 012, India \\ (Requests for offprints should be addressed to P Kondaiah; Email: paturu@serc.iisc.ernet.in)
}

\begin{abstract}
The male accessory sex organs and epididymis regress following androgen depletion, although the onset of apoptosis varies temporally depending upon the tissue type. Transforming growth factor- $\beta 1$ (TGF- $\beta 1)$ is an androgen-repressed gene and believed to be an apoptotic agent in the regressing rat ventral prostate (VP). Hence, in order to investigate the status of TGF- $\beta$ isoforms following castration in androgen-dependent tissues other than VP, this study was undertaken. Northern blot analysis using total RNA from these tissues of intact animals showed higher levels of TGF- $\beta 1$ expression as compared with VP, indicating a function other than that of an apoptotic agent for this isoform. Following orchiectomy, TGF- $\beta 1$ was induced in all organs studied and the levels were highest at day 3 following castration in seminal vesicle $(\mathrm{SV})$ and the epididymis and decreased by
\end{abstract}

day 5 despite the absence of androgens. This observation implies that TGF- $\beta 1$ might not be a truly androgen-repressed gene in these tissues. TGF- $\beta 2$ was up-regulated in VP, SV, caput and corpus epididymis but was undetectable in the dorsolateral prostate and cauda epididymis. On the other hand, TGF- $\beta 3$ expression was refractory to the androgen status in corpus epididymis and $\mathrm{SV}$ but was up-regulated in the remaining tissues. The castration-induced induction of mRNAs was attenuated after exogenous androgen administration. Most importantly, all the isoforms differed significantly in the time and magnitude of induction following castration, suggesting that a single hormone, testosterone, modulates the expression of TGF- $\beta$ s in an isoform- and tissue-specific manner. Fournal of Molecular Endocrinology (2000) 24, 253-260

\section{INTRODUCTION}

The transforming growth factors- $\beta$ (TGF- $\beta$ s) are versatile peptide modulators of cell function and influence several processes including tissue remodeling and repair, development and differentiation of organ systems, carcinogenesis and immunesuppression (Roberts et al. 1988). TGF- $\beta$ s are potent inducers of extracellular matrix production and growth inhibitors of epithelial cells (Massague 1990). Three distinct isoforms have been identified in mammals, and these differ spatially and temporally in their tissue distribution (Roberts \& Sporn 1990). The non-overlapping phenotypes of mice null for individual isoforms have underscored the functional independence of each isotype in vivo (Shull et al. 1992, Kulkarni et al. 1993, Kaartinen et al. 1995, Proetzel et al. 1995, Sanford et al. 1997).
In the male reproductive system, TGF- $\beta 1$ has been implicated in the morphogenesis of the rat neonatal seminal vesicle (SV) and ventral prostate (VP) (Tanji et al. 1994, Timme et al. 1994). Also, TGF- $\beta 1$ is an androgen-repressed gene and an apoptotic agent in the regressing VP (Kyprianou \& Isaacs 1989). Several lines of evidence suggest a specific role for TGF- $\beta$ s during prostate carcinogenesis (reviewed in Barrack 1997, Lee et al. 1999). In addition to the VP, the dorsolateral prostate (DLP) lobes, the SVs and epididymis are targets of androgen action and regress following androgen depletion. The magnitude and time of onset of cell death post androgen depletion vary depending on the tissue and cell type under consideration (Wahlqvist et al. 1996, Yamashita et al. 1996). As TGF- $\beta$ s are implicated in apoptosis, it is important to study the pattern of isoform expression following 
A

I $\mathrm{C} 1 \mathrm{C} 3 \mathrm{C} 5 \mathrm{C} 3+\mathrm{T}$
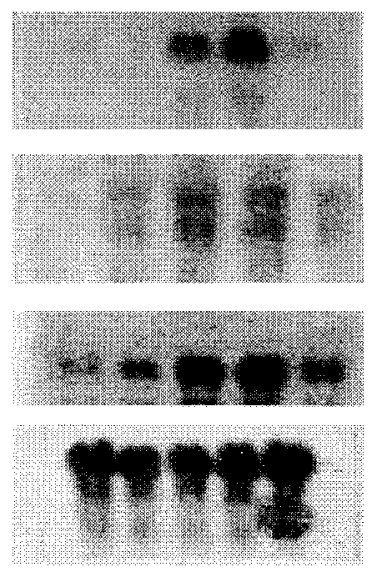

B

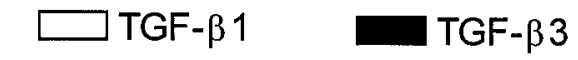

TGF-B1

TGF-ß2

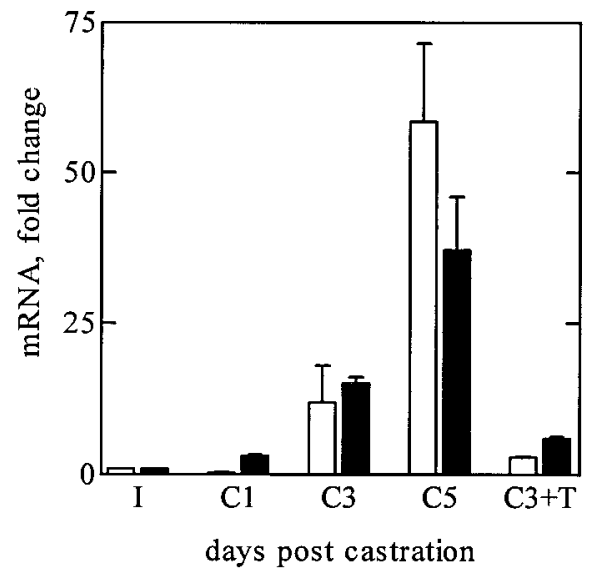

FIGURE 1. Northern blot analysis of TGF- $\beta$ isoforms in the VP following castration and subsequent testosterone injection. Total RNA $(20 \mu \mathrm{g})$ was analyzed on a $1 \cdot 2 \%$ agarose formaldehyde gel, transferred onto nylon membrane and hybridized to gene-specific probes. 18S rRNA was used to normalize the amount of RNA in each lane. (A) I, intact prostate; C1, day 1 post castration; C3, day 3 and $\mathrm{C} 5$, day 5 post castration; C3+T, three daily injections of testosterone after day 3 post castration. (B) Results of densitometric scans of the Northern blots showing fold change in the mRNAs of TGF- $\beta 1$ and TGF- $\beta 3$ in three independent experiments. TGF- $\beta$ isoforms appear to be androgen-repressed genes in VP.

castration in all these tissues. We have previously reported the differential distribution of TGF- $\beta$ isoforms in the accessory sex glands and epididymis (Desai et al. 1998). This study describes the castration-induced modulation of TGF- $\beta$ isoform expression. The results indicate that androgen depletion leads to differential modulation of TGF- $\beta$ s depending upon the isoform and tissue type under consideration.

\section{MATERIALS AND METHODS}

\section{Animals}

Male Wistar rats (IISc strain) aged 60-70 days were maintained according to the guidelines of the institute. In each cage, four animals were housed with access to rat chow and water ad libitum. Animals were castrated surgically via scrotal incision under ether anesthesia and killed by cervical dislocation on day $1(\mathrm{C} 1)$, day $3(\mathrm{C} 3)$ and day 5 (C5) post operation. On $\mathrm{C} 3$, an independent group received $1 \mathrm{mg}$ testosterone/kg body weight intraperitoneally in polyethylene glycol $(\mathrm{C} 3+\mathrm{T})$. The control group included sham-castrated animals (I). The male accessory sex organs and the epididymis were dissected out, cleaned of debris, snap frozen in liquid nitrogen and stored at $-70{ }^{\circ} \mathrm{C}$ until further use.

\section{Northern blot analysis}

Frozen tissue samples were used for extraction of total RNA using one-step purification by guanidium isothiocyanate (Chomczynski \& Sacchi 1987). RNA concentration was determined by measuring absorbance at $260 \mathrm{~nm}$ and the purity was assessed by the ratio of absorbance at $260 / 280 \mathrm{~nm}$. Total RNA $(20-40 \mu \mathrm{g})$ was resolved on a $1 \cdot 2 \%$ agaroseformaldehyde gel, blotted onto Hybond-N nylon membrane (Amersham International plc, Amersham, Bucks, UK) and sequentially hybridized to TGF- $\beta$ isoform-specific probes (Denhez et al. 1990, Qian et al. 1990, Millan et al. 1991) by the method of Church \& Gilbert (1984). The cDNAs were labeled using a Megaprime labeling kit (Amersham International plc) using $\alpha_{-}{ }^{32} \mathrm{P}-\mathrm{dCTP}$ (specific activity $3000 \mathrm{Ci} / \mathrm{mmol}$; NEN, Dupont, Boston, MA, USA). Prehybridization was carried out for $30 \mathrm{~min}$ at $65{ }^{\circ} \mathrm{C}$ in a buffer containing $1 \%$ bovine serum albumin, 7\% SDS, $1 \mathrm{mM}$ EDTA and $0 \cdot 5 \mathrm{M}$ disodium hydrogen phosphate $(\mathrm{pH} \quad 7 \cdot 0)$. 
A

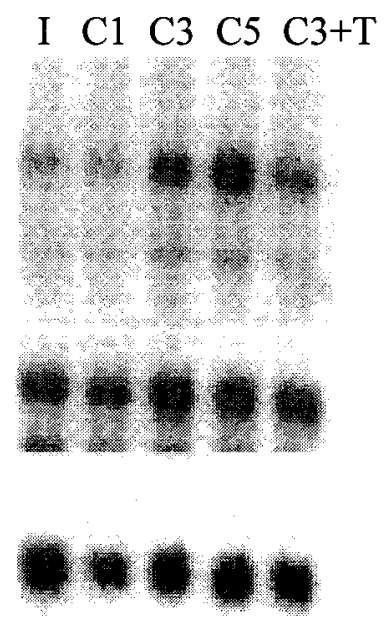

B

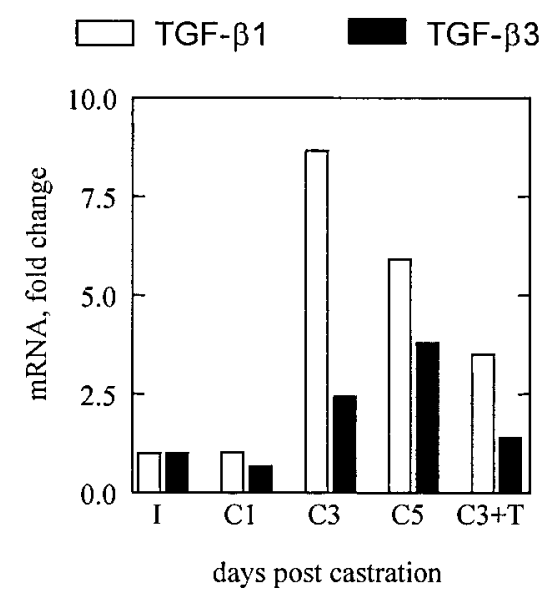

FIGURE 2. Modulation of TGF- $\beta$ isoforms in the DLP. (A) A representative blot hybridized to TGF- $\beta 1$ and TGF- $\beta 3$ isoforms and GAPDH cDNAs. TGF- $\beta 1$ was induced by C3, and decreased by C5, whereas TGF- $\beta 3$ is marginally induced following castration. The TGF- $\beta 2$ mRNA could not be detected in this organ probably due to extremely low levels of expression. (B) Results of quantitative analysis of the Northern blots shown in (A).

A

I $\mathrm{C} 1 \mathrm{C} 3 \mathrm{C} 5 \mathrm{C} 3+\mathrm{T}$

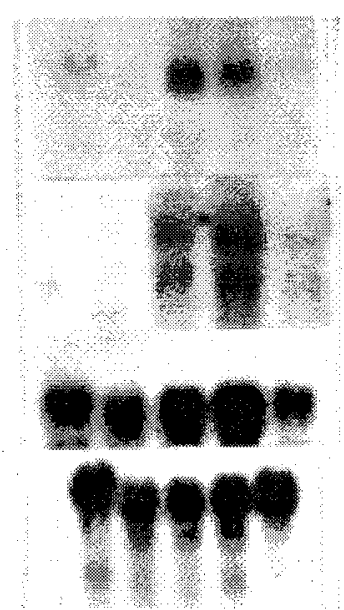

B

TGF- $\beta 1$

TGF- $\beta 2$

TGF- $\beta 3$

18S rRNA
TGF- $\beta 1$

TGF- $\beta 3$

GAPDH
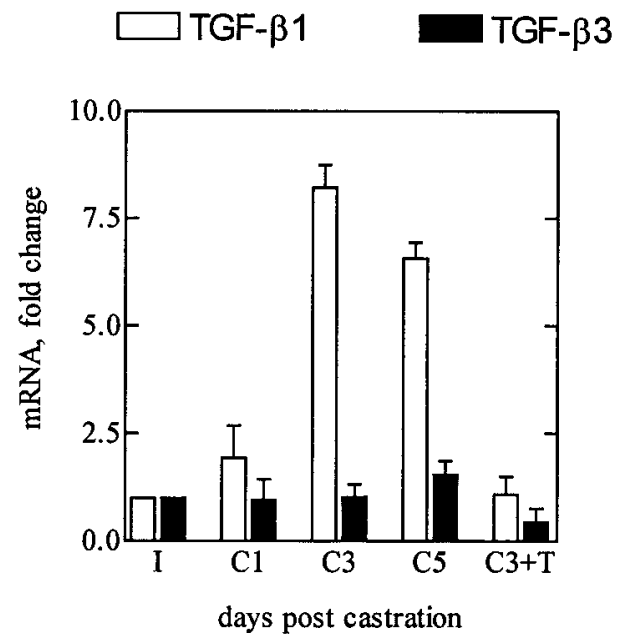

FIGURE 3. Castration-induced modulation of TGF- $\beta$ isoforms in the rat SV. (A) Total RNA was isolated from SV at $\mathrm{C} 1, \mathrm{C} 3$ and $\mathrm{C} 5$ following castration and $20 \mu \mathrm{g}$ of this RNA was hybridized sequentially to TGF- $\beta 1$, TGF- $\beta 3$ and $18 \mathrm{~S}$ rRNA probes. RNA $(40 \mu \mathrm{g})$ was used for hybridization of TGF- $\beta 2$-specific cDNA. The results show that the TGF- $\beta 2$ gene was androgen repressed in this organ and was down-regulated upon testosterone treatment $(\mathrm{C} 3+\mathrm{T})$. In contrast, TGF- $\beta 3$ was refractory to the androgen status and TGF- $\beta 1$ was induced at C3 but was down-modulated by C5. (B) Densitometric scanning of the blots obtained in three independent experiments.

Blots were hybridized with $3 \times 10^{6}$ c.p.m. labeled $\mathrm{cDNA} / \mathrm{ml}$ pre-hybridization buffer for $16 \mathrm{~h}$ at $65{ }^{\circ} \mathrm{C}$. The non-specific interactions were minimized by washing the blots with $2 \times \mathrm{SSC} / 0 \cdot 1 \% \mathrm{SDS}$ at room temperature for $30 \mathrm{~min}(3 \times 10 \mathrm{~min})$ followed by another $30 \mathrm{~min}$ with $0 \cdot 2 \times \mathrm{SSC} / 0 \cdot 1 \%$ $\mathrm{SDS}$ at $65{ }^{\circ} \mathrm{C}(3 \times 10 \mathrm{~min})$. The blots were exposed to Hyperfilm (Amersham International plc) 
$\mathbf{A}$

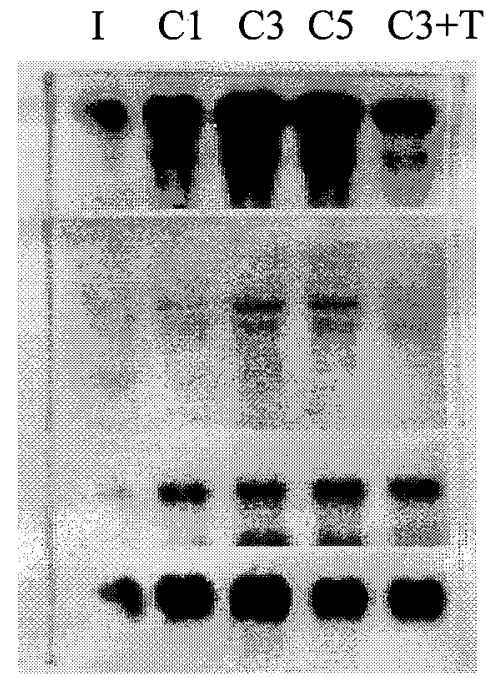

C

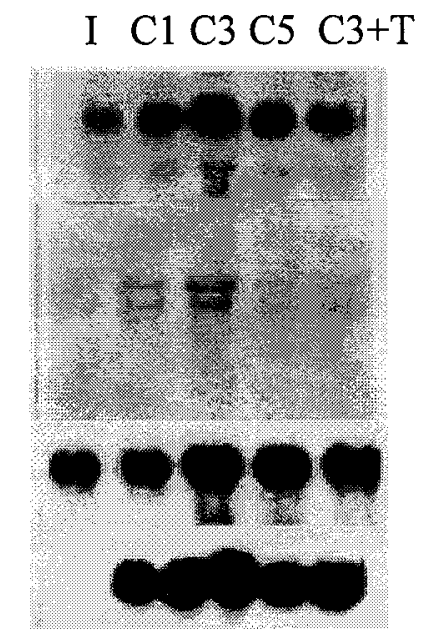

$\mathbf{E}$

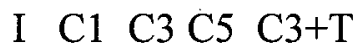

TGF- $\beta 1$

TGF- $\beta 2$

TGF- $\beta 3$

GAPDH

TGF- $\beta 1$

TGF- $\beta 2$

TGF- $\beta 3$

GAPDH
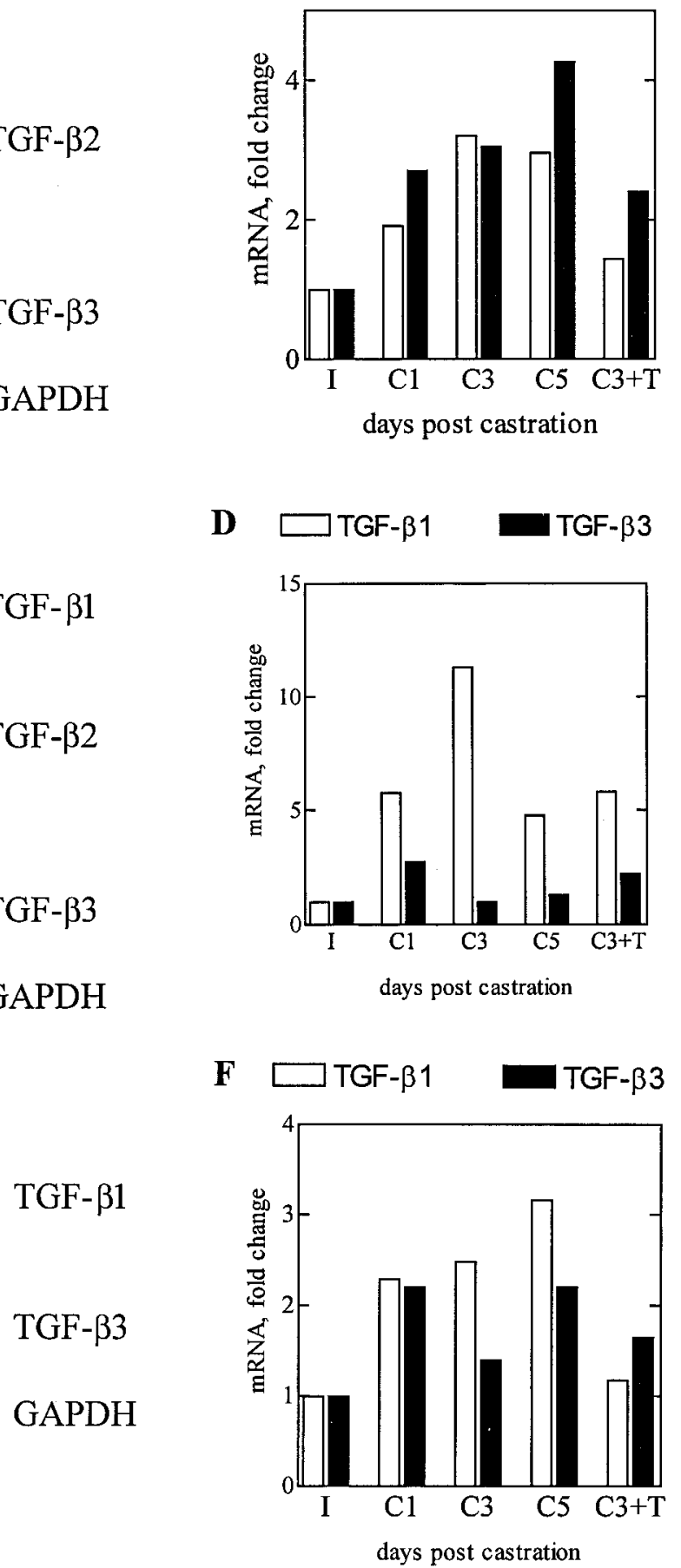

D $\square$ TGF- $\beta 1 \square$ TGF- $\beta 3$

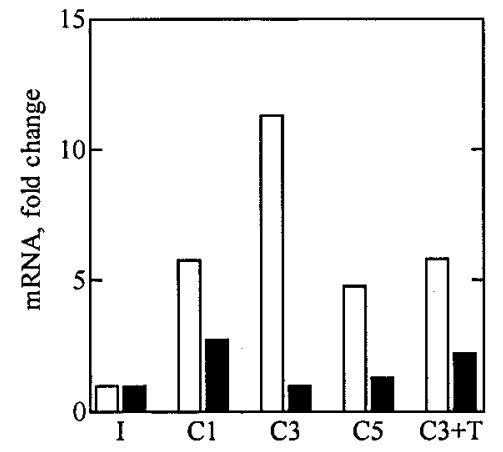

days post castration
B $\square$ TGF- $\beta 1 \square$ TGF- $\beta 3$

www.endocrinology.org 
at $-70{ }^{\circ} \mathrm{C}$ and the signals obtained after suitable exposure times were quantified by a scanning laser densitometer (Ultroscan; Pharmacia Biotech, Piscataway, NJ, USA). In each experiment, five animals were used per group and each experiment was performed three times. The values obtained for respective cDNA probes were normalized to those obtained for 18S rRNA and/or glyceraldehyde 3 -phosphate dehydrogenase (GAPDH) gene. The data from the I group value was taken as one arbitrary unit and various test samples were plotted as fold change over the control values.

\section{RESULTS}

In the organs studied, TGF- $\beta 1$ predominantly displayed $2.5 \mathrm{~kb}$ mRNA and $1.9 \mathrm{~kb}$ transcript was detected following induction. TGF- $\beta 2$ displayed 4.8 and $3.8 \mathrm{~kb}$ transcripts, whereas a single $3.5 \mathrm{~kb}$ transcript was detected for TGF- $\beta 3$.

\section{Ventral prostate}

Orchiectomy was performed on male rats and animals were killed on $\mathrm{C} 1, \mathrm{C} 3$, and $\mathrm{C} 5$ post operation. Sham-castrated animals served as intact controls (I). In parallel, a C3 group was injected with testosterone daily for a period of 3 days $(\mathrm{C} 3+\mathrm{T})$. Total RNA isolated from the rat VP was subjected to Northern blot analysis. Hybridization of isoform-specific probes to the blot revealed massive induction of all the three isoforms of TGF- $\beta$ post castration (Fig. 1A). A tenfold induction of the TGF- $\beta 1$ transcript was observed in $\mathrm{C} 3$ animals, and this increased to almost 50-fold in C5. The TGF- $\beta 2$ expression was analyzed on a duplicate blot and displayed 4.8 and $3.8 \mathrm{~kb}$ transcripts out of the four mRNA species reported for murine TGF- $\beta 2 \mathrm{mRNA}$. The detected messages were up-regulated upon androgen withdrawal. Amounts of TGF- $\beta 2 \mathrm{mRNA}$ isolated from intact animals were undetectable and hence densitometric scanning of these blots was not feasible. In the intact group, TGF- $\beta 3$ was expressed to a greater extent than either the TGF- $\beta 1$ or the TGF- $\beta 2$ isoform. TGF- $\beta 3$ was induced to about 15 -fold in
$\mathrm{C} 3$ and 35-fold in C5 samples in comparison with control levels. At $\mathrm{C} 3+\mathrm{T}$, all observed inductions in the steady-state levels of mRNA were attenuated to near control levels. The densitometric analysis of the Northern blots is shown in Fig. 1B.

\section{Dorsolateral prostate}

Northern blot analysis of total RNA isolated at the experimental time-points from DLP revealed the presence of increased expression of TGF- $\beta 1 \mathrm{mRNA}$ following castration. At $\mathrm{C} 3$, an increase of eight- to ninefold was detected which decreased to sixfold by C5. The TGF- $\beta 3$ transcript showed a modest fourfold induction at C5 (Fig. 2). Both inductions could be abolished by androgen treatment. In this tissue, TGF- $\beta 2$ specific transcripts could not be detected, presumably because of extremely low levels of expression. Hence, the influence of androgen depletion could not be evaluated with regard to this isoform in DLP.

\section{Seminal vesicle}

As compared with the rat VP, SV displayed much higher levels of TGF- $\beta 1$ transcript in the intact animals. Following castration, TGF- $\beta 1$ was induced by eightfold at $\mathrm{C} 3$ and the mRNA levels decreased by $\mathrm{C} 5$ to sixfold above intact levels (Fig. 3). TGF- $\beta 2$ mRNA was progressively induced upon castration in a manner similar to that observed in the VP. The TGF- $\beta 3$ mRNA levels in this organ remained relatively unchanged upon androgen depletion. All castration-induced expressions were down-modulated upon testosterone treatment.

\section{Epididymis}

The three regions of epididymis, the caput (E1), corpus (E2) and cauda (E3), varied remarkably in the pattern of TGF- $\beta$ modulation (Fig. $4 \mathrm{~A}, \mathrm{~B}$ and $\mathrm{C})$. In all the three regions, substantial expression of TGF- $\beta 1$ mRNA was observed in the intact group of animals as opposed to low levels of both TGF- $\beta 2$ and TGF- $\beta 3$ isoforms. Two transcripts, $2 \cdot 5 \mathrm{~kb}$ and $1.9 \mathrm{~kb}$, were detected in the epididymis. Androgen ablation resulted in the enhancement of the

FIGURE 4. Modulation of TGF- $\beta$ isoform expression in the three regions of the epididymis. (A, C and E) Northern blot analysis using TGF- $\beta$ isoform-specific probes. (B, D and F) Densitometric analysis of the respective blots. (A and $\mathrm{B})$ The caput region (E1), (C and D) the corpus region (E2) and (E and F) the cauda epididymis (E3). TGF- $\beta 1$ isoform was induced following castration in E1, E2 and E3 regions although to a variable extent. On the other hand, TGF- $\beta 2$ was detectable only in the E1 and E2 regions wherein it was up-regulated following castration. Interestingly, TGF- $\beta 3$ expression remained unchanged following castration in the E2 and E3 regions but was up-regulated in the E1 region. 
steady-state levels of both the TGF- $\beta 1 \mathrm{mRNA}$ species to about three- to fourfold over intact levels in the E1 and E3 regions and approximately tenfold in E2. This induction could be nullified by testosterone treatment. The TGF- $\beta 2 \mathrm{mRNA}$ was progressively induced up to $\mathrm{C} 5$ in $\mathrm{E} 1$, was highest in $\mathrm{E} 2$ at day 5 but the transcripts were undetectable in the $\mathrm{E} 3$ region of the epididymis. The TGF- $\beta 3$ isoform displayed an interesting pattern of regulation. It was induced threefold in the E1 region, modulated marginally in E3 but remained unaffected in the corpus region (E2) following castration.

\section{DISCUSSION}

Androgens control the growth, development and differentiation of the male accessory sex glands and epididymis. Androgen ablation leads to the regression of these organs, albeit at different rates, by the process of apoptosis (Wahlqvist et al. 1996, Yamashita et al. 1996). The involution of VP has been studied extensively and TGF- $\beta 1$ has been implicated in the apoptotic cell death following castration (Kyprianou \& Isaacs 1988, 1989, Banerjee et al. 1995). To ascertain if TGF- $\beta$ s are modulated by androgen depletion in a similar manner in the other accessory sex glands and epididymis, their regulation was studied following castration.

In addition to the castration-induced modulation of TGF- $\beta 1$ isoform in the rat VP, we report the castration-induced up-regulation of the other two mammalian isoforms, TGF- $\beta 2$ and TGF- $\beta 3$. Hence, all three isoforms could be considered testosterone-repressed mRNAs in the rat ventral prostate. The results for TGF- $\beta 2$ and TGF- $\beta 3$ isoforms in the intact 60 -day-old rats (low expression of TGF- $\beta 2$ and high mRNA for TGF- $\beta 3$ ) were in agreement with those obtained by Itoh et al. (1998). The same study, however, did not demonstrate the induction of TGF- $\beta 3$ following castration. In the present study, a tenfold upregulation of the TGF- $\beta 3 \mathrm{mRNA}$ at $\mathrm{C} 3$ which progressively increased to 35 -fold by $\mathrm{C} 5$ was observed. This discrepancy might be due to different methodologies employed. Itoh et al. (1998) have studied the modulation of TGF- $\beta$ isoforms by a semiquantitative RT-PCR approach whereas Northern blot analysis was carried out in the present study.

The basal expression of TGF- $\beta$ isoforms in all other tissues was much higher than in VP, perhaps reflecting less sensitivity to androgen repression and suggesting a physiological function other than induction of apoptosis. SV secretes various protease inhibitors as constituents of semen and TGF- $\beta 1$ is known to induce several such inhibitors, including plasminogen activator inhibitor and tissue inhibitors of matrix metalloproteinases (reviewed by Massague 1990). TGF- $\beta 1$ induces the contractility of peritubular myoid cells of the testis (Tung \& Fritz 1991). The sperm in the epididymis is immotile and its passage through this organ requires efficient contraction of the tubules. Hence, TGF- $\beta$ s may serve to induce such contractions in intact animals. Modulation of TGF- $\beta 1$ isoform following castration was evident in all these organs, although the level of induction was much lower in comparison with VP. Administration of testosterone to castrated animals resulted in the down-modulation of induced mRNAs. As opposed to the progressive up-modulation seen in the VP, caput and cauda epididymis, in $\mathrm{SV}$, corpus epididymus and DLP maximal induction of TGF- $\beta 1$ was observed at C3, which decreased by $\mathrm{C} 5$. This observation suggests that, in these tissues, induction of TGF- $\beta 1$ appears to be transient and, as the levels of $\mathrm{mRNA}$ in these organs fall by $\mathrm{C} 5$ prior to testosterone replacement, TGF- $\beta 1$ does not appear to be a truly androgenrepressed gene. Recent studies by Yuasa et al. (1999) have shown that TGF- $\beta 1$ is localized to the basal epithelial cells of $\mathrm{SV}$ in immature castrated and estrogen-treated rats, implying its importance in epithelial-mesenchymal interactions following castration.

Although induction of TGF- $\beta 1 \mathrm{mRNA}$ was observed in the caput, corpus, and cauda epididymis, previous studies have demonstrated that only the caput region nearest to the testis regresses irreversibly post castration. The proximity of the caput region to the testis results in its exposure to very high local testosterone concentrations and, hence, caput cells may require such high levels of androgen and other luminal or testicular factors for regeneration. As they cannot be achieved by exogenous administration of the hormone, the caput regression may remain irreversible (Fawcett \& Hoffer 1979). Despite irreversible loss of cells, testosterone application down-regulated the induced TGF- $\beta 1$ expression in the caput region. The second intriguing observation was the induction of TGF- $\beta 1$ as early as $\mathrm{C} 3$ in the corpus and the cauda regions which showed apoptosis of principal cells after 5-7 days of androgen withdrawal (Fan \& Robaire 1998). These observations reinforce the speculation that this growth factor indeed serves a function other than that of an apoptotic agent.

The detection of TGF- $\beta 2$ specific transcripts was difficult as this isoform is expressed in very low amounts in most of the organs and cell lines studied 
so far. The organs from intact animals did not have detectable levels of TGF- $\beta 2$ mRNAs. In the VP, $\mathrm{SV}$, caput and cauda epididymis, castration led to an enhanced expression of the TGF- $\beta 2$ mRNAs by $\mathrm{C} 3$, which was maintained up to $\mathrm{C} 5$. Although various transcripts of TGF- $\beta 2$ have been reported, only 4.8 and $3.8 \mathrm{~kb}$ mRNAs were evident in these tissues. On the other hand, TGF- $\beta 2$ mRNA was undetectable in the total RNA isolated from cauda epididymis and DLP at all experimental timepoints studied.

In contrast to the castration-induced upregulation of TGF- $\beta 1$ expression in all tissues examined, TGF- $\beta 3$ expression in $\mathrm{SV}$ and cauda epididymis remained unchanged following castration. Hence, this isoform appears to be refractory to androgen status in these tissues. We have previously shown differential localization of TGF- $\beta 3$ in the epithelial cells of the corpus epididymis (Desai et al. 1998). Interestingly, in corpus epididymus this isoform was not modulated following androgen depletion. The caput epididymis and DLP displayed a marginal induction of three- to fivefold of TGF- $\beta 3$ by $\mathrm{C} 3$ as opposed to the massive induction of TGF- $\beta 3$ expression observed in the VP.

These observations indicate that differential regulatory mechanisms are probably involved in the modulation of the TGF- $\beta$ isoforms by androgens. Detailed investigation of each of these observations will provide a myriad of mechanisms by which androgens regulate the TGF- $\beta$ subfamily. In conclusion, androgen regulation of TGF- $\beta$ isoforms appears to be cell- and tissue type-specific and possibly via independent and differential molecular mechanisms.

\section{ACKNOWLEDGEMENTS}

This study was supported by the 'Contraception 21' program of the Rockefeller Foundation, USA.

\section{REFERENCES}

Banerjee PP, Banerjee S, Tilly KI, Tilly JL, Brown TR \& Zirkin BR 1995 Lobe-specific apoptotic cell death in rat prostate after androgen ablation by castration. Endocrinology 136 4368-4376.

Barrack ER 1997 TGF beta in prostate cancer: a growth inhibitor that can enhance tumorigenicity. Prostate 31 61-70.

Chomczynski P \& Sacchi N 1987 Single step method of RNA isolation by acid guanidium thiocyanate-phenol-chloroform extraction. Analytical Biochemistry 162 156-159.

Church GM \& Gilbert W 1984 Genomic sequencing. Proceedings of the National Academy of Sciences of the USA 81 1991-1995.
Denhez F, Lafyatis R, Kondaiah P, Roberts AB \& Sporn MB 1990 Cloning by polymerase chain reaction of a new mouse TGF- $\beta$, mTGF- $\beta 3$. Growth Factors 3 139-146.

Desai KV, Flanders KC \& Kondaiah P 1998 Expression of transforming growth factor beta isoforms in the rat male accessory sex glands and epididymis. Cell and Tissue Research 294 271-277.

Fan X \& Robaire B 1998 Orchidectomy induces a wave of apoptotic cell death in the epididymis. Endocrinology 139 2128-2136.

Fawcett DW \& Hoffer AP 1979 Failure of exogenous androgen to prevent regression of the initial segment of the rat epididymis after efferent duct ligation or orchiectomy. Biology of Reproduction 20 162-181.

Itoh N, Patel U, Cupp AS \& Skinner MK 1998 Developmental and hormonal regulation of transforming growth factor-beta1, -2 , and -3 gene expression in isolated prostatic epithelial and stromal cells: epidermal growth factor and TGF-beta interactions. Endocrinology 139 1378-1388.

Kaartinen V, Voncken JW, Schuler C, Warburton D, Bu D, Heistercamp N \& Groffen J 1995 Abnormal lung development and cleft palate in mice lacking TGF- $\beta 3$ indicates defects of epithelial-mesenchymal interaction. Nature Genetics 11 415-421.

Kulkarni AB, Chang-Goo Huh, Becker D, Geiser A, Lyght M, Flanders KC, Roberts AB, Sporn MB, Ward JM \& Karlsson S 1993 Transforming growth factor $\beta 1$ null mutation in mice causes excessive inflammatory response and early death. Proceedings of the National Academy of Sciences of the USA $90770-774$.

Kyprianou N \& Isaacs JT 1988 Activation of programmed cell death in the rat ventral prostate after castration.

Endocrinology 122 552-562.

Kyprianou N \& Isaacs JT 1989 Expression of transforming growth factor- $\beta$ in the rat ventral prostate during castrationinduced programmed cell death. Molecular Endocrinology 3 1515-1522.

Lee C, Sintich SM, Mathews EP, Shah AH, Kundu SD, Perry KT, Cho JS, Ilio KY, Cronauer MV, Janulis L \& Sensibar JA 1999 Transforming growth factor- $\beta$ in benign and malignant prostate. Prostate 39 285-290.

Massague J 1990 The transforming growth factor-beta family. Annual Review of Cell Biology 6 597-641.

Millan FA, Denhez F, Kondaiah P \& Akhurst RJ 1991 Embryonic gene expression patterns of TGF $\beta 1, \beta 2$ and $\beta 3$ suggest different developmental functions in vivo. Development 111 131-144.

Proetzel G, Pawlowski S, Wiles MV, Yin M, Boivin GP, Howles PN, Ding J, Ferguson MWJ \& Doetschman T 1995 Transforming growth factor- $\beta 3$ is required for secondary palate fusion. Nature Genetics 11 409-414.

Qian SW, Kondaiah P, Roberts AB \& Sporn MB 1990 cDNA cloning by PCR of rat transforming growth factor $\beta-1$ Nucleic Acids Research 183059.

Roberts AB \& Sporn MB 1990 The transforming growth factor- $\beta$ s. In Peptide Growth Factors and their Receptors. Hand Book of Experimental Pharmacology, pp 419-472. Eds MB Sporn \& AB Roberts. Germany: Springer-Verlag.

Roberts AB, Flanders KC, Kondaiah P, Thompson NL, van Obberghen-Schilling E, Wakefield L, Rossi P, deCombrugghe B, Heine U \& Sporn MB 1988 Transforming growth factor- $\beta$ : biochemistry and roles in embryogenesis, tissue repair and remodeling, and carcinogenesis. Recent Progress in Hormone Research 44 157-197.

Sanford PL, Ormsby I, Gittenberger-de Groot AC, Sariola H, Freidman R, Boivin GP, Cardell EL \& Doetschman T 1997 TGF $\beta 2$ knockout mice have multiple developmental defects 
that are nonoverlapping with other TGF $\beta$ knockout phenotypes. Development 124 2659-2670.

Shull MM, Ormsby I, Kier AB, Pawlowski S, Diebold RJ, Yin M, Allen R, Sidman C, Proetzel G, Calvin D, Annunziata N \& Doetschman T 1992 Targeted disruption of the mouse transforming growth factor- $\beta 1$ gene results in multifocal inflammatory disease. Nature 359 693-699.

Tanji N, Tsuji M, Terada N, Takeuchi M \& Cunha GR 1994 Inhibitory effects of transforming growth factor- $\beta 1$ on androgen-induced proliferation of neonatal mouse seminal vesicles in vitro. Endocrinology 134 1155-1162.

Timme T, Truong LD, Merz V, Krebs T, Kadmon D, Flanders KC, ParkSH \& Thompson TC 1994 Mesenchymal-epithelial interactions and TGF $\beta$ expression during mouse prostate morphogenesis. Endocrinology 134 1039-1045.

Tung PS \& Fritz IB 1991 Transforming growth factor beta and platelet derived growth factor synergistically stimulate contraction of testicular peritubular cells in culture in serum free medium. Fournal of Cellular Physiology 146 386-393.

Wahlqvist R, Dahl E \& Tveter KJ 1996 Effects of castration upon the morphology of the accessory sex organs of the male rat - a scanning electron microscopy study. Scanning Microscopy 10 1155-1162.

Yamashita A, Hayashi N, Sugimura Y, Cunha GR \& Kawamura J 1996 Influence of diethylstilbestrol, leuprolelin (a lutenizing hormone-releasing hormone analog), finasteride ( $5 \alpha$-reductase inhibitor), and castration on the lobular subdivisions of the rat prostate. Prostate 29 1-14.

Yuasa H, Fukabori Y, Ono Y, Tomita N, Suzuki K \& Yamanaka H 1999 Immunohistochemical characteristics of estrogen receptor alpha positive cells in glandular epithelium of the rat seminal vesicle. Tohoku Fournal of Experimental Medicine 7 25-35.

RECEIVED 29 September 1999 